\title{
ANALYSIS OF ANTIOXIDANT PROPERTIES, TOXICITY AND MINERAL COMPOSITION OF SELECTED APPLE (MALUS DOMESTICA BORKH) VARIETIES FROM BALOCHISTAN
}

\author{
Ajab Khan Tareen, Muhammad Anwar Panezai, Ashif Sajjad, Jahangir Khan Achakzai, Abdul Manan Kakar \\ and Nazima Yousaf Khan \\ Institute of biochemistry, University of Balochistan, Quetta 87300, Pakistan
}

https://doi.org/10.35410/IJAEB.2021.5680

\begin{abstract}
We assessed total phenolic content (TPC), total flavonoid content (TFC), free radical quenching capacities in terms of 2,2-diphenyl-1-picrylhydrazyl hydrate (DPPH), TAC (Total Antioxidant Capacity), Hydrogen Peroxide Scavenging (HPS), ferric reducing Antioxidant power (FRAP), acute and chronic toxicity assays and mineral contents in the peel and pulp of five varieties of apple (Malus domestica Borkh.) fruit from Balochistan province. The peel extracts of tested varieties exhibited significantly $(\mathrm{p}<0.05)$ substantial amount of TPC, TFC and extraction yield, predominantly in the peel of Red Delicious. In terms of half maximal inhibitory concentration (IC50) values Katja pulp exhibited lowest values in all the in vitro antioxidant assays. Luminescence-based assays showed that all the tested peel and pulp extracts exhibited toxicity towards V. logei only at high concentration and maximum contact time. Furthermore, significant correlation between TPC and DPPH, TAC, FRAP and HPS assays were found, demonstrating that phenolics contribute to antioxidant capacity. Pertaining to the mineral analysis, both fruit tissues revealed the concentration of $\mathrm{K}$ to be maximum, preceded by $\mathrm{Ca}, \mathrm{Na}, \mathrm{Fe}, \mathrm{Mn}, \mathrm{Co}, \mathrm{Cu}$ and $\mathrm{Cd}$. Obtained results impart information on nutritional, antimicrobial and phytochemical composition of analyzed apple varieties and thereby inspire their consumption and cultivation.
\end{abstract}

Keywords: Malus domestica Borkh, Phenolic, Antioxidant activity, Minerals.

\section{INTRODUCTION}

Recently research trend is focused on the study of healthy foods and natural products due to their potential use as means of biologically active compounds and their consecutive connection in treating and mitigating diseases [1]. The significant constituents from the natural sources are polyphenolic compounds, which are described to have major antioxidant prospective [2]. One good source of phenolic compounds for humans, are apples which are source of dietary antioxidants, belongs to the family Rosaceae, is a tasty and is the fourth most widely grew fruit across the globe [3]. Apple fruit (Malus domestica Borkh) has captured enormous consideration for its putative and salubrious health advantages in the last 10 years. Several studies from various regions of the world recognized that apples are an efficient source of antioxidant phenolics, minerals, dietary fibers, and carbohydrates[4]-[6].

Epidemiological studies have manifested converse relationship between the intakes of apples and/or associated products and the possibility of lung dysfunctions, cardiovascular diseases, and several types of cancers, especially colon, liver and prostate [7]. The health- 
Vol. 06, No. 06; 2021

ISSN: $2456-8643$

protecting features of apple fruits have been ascribed to the existence of polyphenols [8]. Apart from phytochemicals, the information pertaining to the concentration of essential minerals is of great significance, since activity of more than one-third of all human proteins rely on them [9].

Balochistan province is the largest grower of fruits in Pakistan, hence popular as "fruit basket of Pakistan". Apples are the first largest growing and second most produced fruit after dates in the province. In Pakistan approximately 0.991 million tons of total fruits are produced from an area of 0.239 million hectares. Balochistan shares $17.4 \%$ and $32.6 \%$ of the country production and area, respectively. It covers an area of 0.101 million hectares with a production of 0.224 million tons. Apple contributing more than $42 \%$ and $23 \%$ of total areas and production of the country's respectively [10]. Various varieties of apple being grown in Balochistan province are Golden Delicious, Amri, Red Delicious, Kashmiri, Mashadi and a newly introduced early maturing variety Katja. The most popular apple producing areas of Balochistan province are Zairat, Quetta, Pishin, Kanozai and Khuzdar districts.

Interestingly, handful studies have been conducted pertaining to the antioxidant activity (AoA) and phenolic study of different cultivar and parts of apple fruit from different regions of the world[5], [6], [11]-[13].

However, no reports on the antioxidant capacity, total phenolic contents, mineral composition and bioluminescence based toxicity of different edible parts of apple varieties commonly cultivated in the province is available in the literature. For that reason, in the light of above connection, the present study was aimed to measure and compare total phenolic contents, antioxidant potential, toxicity assays and mineral contents in the peel and pulp parts of selected varieties of apple fruit grown in the province.

\section{MATERIALS AND METHODS}

\subsection{Chemicals and materials}

All the reagents and standards were of analytical grade. Catechin Hydrate, DPPH, Quercetin, Nitric Acid and Sulphuric Acid were from Sigma Chemical Co. (St. Louis, MO, USA). Gallic Acid and Trolox were from Acros (New Jersey, USA). Follin-Ciocaltue Reagent was purchased from Central Drug House (New Delhi, India). Alpha Tocopherol was from MP Biomedicals, Aliant Co. Ltd. (Germany). Sodium Carbonate, Sodium nitrite, Sodium phosphate, Ferric Chloride, Potassium ferricynide, L-Ascorbic Acid, Sodium Hydrogen Diphosphate and Sodium Hydrogen monobasic, Lactose, $\mathrm{MgCl}_{2}$, soluble starch, $\mathrm{CaCl}_{2}$ and glycerol were from Merck (Darmstadt, Germany). Aluminum Chloride and Hydrogen peroxide 35\% were from BDH Chemical Ltd. Analar (UK). Sodium Hydroxide was from Scharlau, (Spain). Tricarboxylic Acid and Ammonium molybdate were from Fisher Scientific (UK). Yeast extract, peptone and bacteriological agar were from Biokar Diagnostics.

\subsection{Fruit material and Sampling}

Five apple varieties namely Amri, Golden Delicious, Katja, Mashadi and Red Delicious grown in the Balochistan province were selected for the present study. Katja and Red Delicious are earlymaturity varieties; Mashadi and Amri are middle-maturity varieties; Golden Delicious is latematurity variety. Fresh, healthy ripe apple fruits of uniform color and variable sizes were harvested randomly from orchards of district Pishin, Quetta, Kanozai and Zairat in July, August 
and September, 2018. The studied varieties were grafted on M9 rootstock, no proper phtosanitory treatment was applied except well rotten farm yard green manure once a year. Fruits were pooled after each harvest. Fruits were authentically identified by horticultural experts at Agriculture Research Institute (ARI), Quetta, Balochistan, Pakistan. The fruits were refrigerated $\left(-18^{\circ} \mathrm{C}\right)$ unless used.

Fresh fruit samples (3 batches, each of 30 apple fruit/variety randomly picked) were peeled off ( $1 \mathrm{~mm}$ thickness) as thin as possible from the pulp and cut into pieces (approximately $1 \times 1 \mathrm{~cm})$ and refrigerated at $-18{ }^{\circ} \mathrm{C}$ unless used. The peel and pulp samples were homogenized in ultra-turrax, T-25 basic homogenizer (IKA, Staufen, Germany) for $10 \mathrm{~min}$.

\subsection{Preparation of the Extracts}

Using the method of [14] with minor changes fresh- homogenized samples (each $200 \mathrm{~g}$ ) was agitated with $200 \mathrm{ml}$ of $80 \%(80: 20 \mathrm{v} / \mathrm{v})$ aqueous methanol for eight hours at room temperature using an orbital shaker (IKA KS 260, Staufen, Germany) at agitation speed of $200 \mathrm{rpm}$ under dim light. Thereafter, filtered through Wattman filter paper No.1. Residues left over were reextracted twice with afresh solvent and pooled. Extracts were desolvinized in rotary evaporator (Stuart, Stone Staffordshire, UK) operated at $35{ }^{\circ} \mathrm{C}$ and at $2 \mathrm{rpm}$ spin speed. The obtained semisolid extracts were dissolved in extraction solvent and stored at $4{ }^{\circ} \mathrm{C}$, until analysis.

\section{DETERMINATION OF MOISTURE CONTENT AND DRY MATTER CONTENT}

Dry matter content (DMC) and moisture content (MC) were assessed by the AOAC protocol [15] (method 925.10). Shortly, (5) g of fresh sample (each) was dried at $80{ }^{\circ} \mathrm{C}$ until constant weight in an electric-oven (Selecta, Spain).

\subsubsection{Determination of extraction Yield}

The yield of the peel and the pulp extracts was measured on a dry weight basis (DWB) by equation 1:

Yield $(\%)=($ Weight of extract $\times 100) /$ Weight of peel or pulp taken

\subsubsection{Determination of Total Phenolic Content (TPC)}

TPC was measured as previously reported by [16]. Briefly, $0.5 \mathrm{ml}$ (containing $0.05 \mathrm{~g} / \mathrm{ml}$ ) of diluted fruit extract was mixed with $0.5 \mathrm{ml}$ Folin-Ciocalteu's reagent (1/10 dilution with deionized water) and deionized water $(8.0 \mathrm{ml})$, incubated for ten minutes, after that added $7.5 \%$ saturated sodium carbonate (w/v, $1.5 \mathrm{ml}$ ) mixed well. After two hours, absorbance was recorded at $750 \mathrm{~nm}$ by Shimadzu-1700 UV-VIS spectrophotometer (Japan) and compared to a calibration curve of prepared gallic acid solutions in the range of $10-250 \mathrm{mg} / \mathrm{L}$. The results are expressed as $\mathrm{mg}$ gallic acid equivalent (GAE) $\mathrm{mg} / 100 \mathrm{~g}$ dry weight (DW).

\subsubsection{Total Flavonoids Contents (TFC)}

The concentration of TFC was assessed as described by [17]. Concisely, $0.5 \mathrm{ml}$ (containing 0.02 $\mathrm{g} / \mathrm{ml})$ of diluted fruit extract was mixed with distilled water $(4 \mathrm{ml})$ in a $10 \mathrm{ml}$ volumetric flasks followed by the addition of ( $3 \mathrm{ml}$ ) of $5 \%$ Sodium Nitrite. After six min, $0.3 \mathrm{ml}$ of $10 \%$ saturated $\mathrm{AlCl}_{3}$ was added and left to stand for another 5 min before $2 \mathrm{ml}$ of $1.0 \mathrm{M} \mathrm{NaOH}$ was mixed. The volume of the reaction mixture was brought up to $10 \mathrm{ml}$ by distilled water and mixed well. 
Vol. 06, No. 06; 2021

ISSN: $2456-8643$

Absorbance was recorded at $510 \mathrm{~nm}$ and compared to a calibration curve of prepared quercetin (QU) solutions in the limit of $10-250 \mathrm{mg} / \mathrm{L}$. Results are expressed as $\mathrm{mg}$ catechin equivalent (CE) $\mathrm{mg} / 100 \mathrm{~g} \mathrm{DW}$.

\subsection{Determination of AoA by DPPH radical-scavenging assay}

Free radicals scavenging activity was appraised as described by [18] with minor modifications. Fresh DPPH solution $(0.1 \mathrm{mM})$ in $100 \mathrm{ml}$ of methanol was prepared from the stock DPPH solution (10 $\mathrm{mM}$ in methanol) in amber bottles for two hours before stabilizing the absorbance. An aliquot of $2 \mathrm{ml}$ of various concentrations $20-120 \mu \mathrm{g} / \mathrm{ml}$ of extract were mixed with $2 \mathrm{ml}$ of DPPH solution and the reaction mixture was vortexed for a min and were kept under dim light for $40 \mathrm{~min}$ at room temperature and decrease in absorbance (Abs.) was measured at $517 \mathrm{~nm}$ against the blank comprises of extract and methanol only. Ascorbic acid and Trolox were used as standards. The radical scavenging activity was determined by equation 2 given below. The linear regression of concentration against absorbance was used to calculate $\mathrm{IC}_{50}(50 \%$ inhibitory concentration) for DPPH and expressed as $\mu \mathrm{g} / \mathrm{ml}$.

DPPH scavenging effect $(\%)=(($ Control Abs. - Test Abs. $) /$ Control Abs. $) \times 100$

(2)

\subsubsection{Determination of AOA by Hydrogen Peroxide Scavenging (HPS) assay} HPS activity was appraised by using the modified method reported by [19]. A hydrogen peroxide solution of $43 \mathrm{mM}$ is briefly prepared in phosphate buffer $(0.1 \mathrm{M}, \mathrm{pH} 7.4)$ from a $0.5 \mathrm{M}$ intermediate stock solution. The latter was prepared from $35 \% \quad \mathrm{H}_{2} \mathrm{O}_{2}$. Sample of various concentrations varying from 50 to $500 \mu \mathrm{g} / \mathrm{ml}$ was dissolved in $3.4 \mathrm{ml}$ of $0.1 \mathrm{M}$ sodium phosphate buffer ( $\mathrm{pH}$ 7.4) and then thoroughly mixed with $0.6 \mathrm{ml}$ of $43 \mathrm{Mm}$ hydrogen peroxide solution (made in the same buffer). The reaction mixture was left for 15 minutes at room temperature under dim light. The amount of unreacted hydrogen peroxide was assessed spectrophotometrically at $230 \mathrm{~nm}$. An additional blank sample without $\mathrm{H}_{2} \mathrm{O}_{2}$ was also prepared for extracts and used for background deduction. Alpha-tocopherol and ascorbic acid were used as standards. Equation 3 was used to measure HPS activity, and linear regression analysis was performed to compute $\mathrm{IC}_{50}$ expressed as $\mu \mathrm{g} / \mathrm{ml}$.

$\left[\mathrm{H}_{2} \mathrm{O}_{2}\right]$ Scavenging effect $(\%)=$ Control Abs.-Test Abs.-Blank Abs. Control Abs. $\times 100$

(3)

\subsubsection{Determination of AoA by Phosphomolybdenium Complex assay}

The total antioxidant capability (TAC) was determined by the method reported by [20] and [21]. Briefly, an aliquot of $3.0 \mathrm{ml}$ of reagent solution $(4 \mathrm{mM}$ ammonium molybdate, $28 \mathrm{mM}$ sodium phosphate, and $0.6 \mathrm{mM}$ sulphuric acid) was mixed to $0.3 \mathrm{ml}$ of extracts of different concentrations varied from 60 to $260 \mu \mathrm{g} / \mathrm{ml}$ in sterile tubes. The tubes were capped and incubated for $90 \mathrm{~min}$ at $95{ }^{\circ} \mathrm{C}$ in a water bath (Clifton, nickel-electro Ltd. UK) and cooled at room temperature. The absorbance of the reaction mixture was taken at $695 \mathrm{~nm}$ against the blank (Methanol). Ascorbic acid and quercetin were used as standards. The TAC sample percentage of inhibition was calculated from the below-mentioned equation 4, and $\mathrm{IC}_{50}$ (representing 50\% reduction) was calculated from the linear regression analysis. 
TAC scavenging effect $(\%)=$ Test absorbance-Control absorbance Test Abs. $\times 100$ (4)

\subsubsection{Determination of Ferric Reducing Antioxidant Power (FRAP) assay}

FRAP assay was measured according to the previously reported modified method [18]. Precisely, mixed $1.0 \mathrm{ml}$ extract of various concentrations (50 to $300 \mu \mathrm{g} / \mathrm{ml}$ ) to $2.5 \mathrm{ml}$ of sodium phosphate buffer $(0.2 \mathrm{M}, \mathrm{pH} 6.6)$ and $2.5 \mathrm{ml}$ of $1 \%(\mathrm{w} / \mathrm{v})$ potassium ferricyanide. The reaction mixture was incubated at $50{ }^{\circ} \mathrm{C}$ for $20 \mathrm{~min}$ in a water bath and sharply cooled. After that, $2.5 \mathrm{ml}$ of $10 \%$ (w/v) of trichloroacetic acid (TCA) were mixed, centrifuged at $3000 \mathrm{rpm}$ for $10 \mathrm{~min} .2 .5 \mathrm{ml}$ of the supernatant was mixed with equal volumes of distilled water and $0.5 \mathrm{ml}$ of ferric chloride $(0.1 \%, \mathrm{w} / \mathrm{v})$. Allowed the reaction mixture to stand for $10 \mathrm{~min}$ at room temperature to develop Perl's Prussian blue color. The absorbance was noted at $700 \mathrm{~nm}$ against the blank (80\% methanol). The sample concentration providing 0.5 of absorbance $\left(\mathrm{IC}_{50}\right)$ was measured from the graph of extract concentration against absorbance values. Ascorbic acid and catechin were used as standards.

\subsection{Bioluminescence (BL) assay for apricot pomace and kernel extracts}

For acute and chronic bioluminescence toxicity assays, a luminescent bacterium $V$. logei (wild strain) was used. The freeze-dried bacterium was prepared and reconstituted as previously described by [22]. Stock solutions of extracts were prepared by mixing dried extracts with distilled water (1:1), which were sequentially diluted with aqueous $3 \% \mathrm{NaCl}$ solution to obtain different dilutions for acute and chronic assays. Wallac Victor 1420 Multilabel Counter luminometer (Wallac, Sweden) and 96 well microplates were used to measure luminescence in relative light units (RLU). For acute toxicity, the inhibition assay was performed by adding to each well $20 \mu \mathrm{l} \mathrm{BL}$ bacteria in culture broth and $180 \mu \mathrm{l}$ of the sample in $3 \% \mathrm{NaCl}$ solution. In comparison, $150 \mu \mathrm{l}$ bacteria and $150 \mu \mathrm{l}$ of the sample in $3 \% \mathrm{NaCl}$ was used for the chronic assay. Similarly, a blank was prepared by adding $3 \% \mathrm{NaCl}$ and $\mathrm{BL}$ bacteria. The emitted light was recorded at intervals of $5 \mathrm{~min}$ for 1 hour in acute and for $20 \mathrm{~h}$ at intervals of $17 \mathrm{~min}$ in chronic assays. Before starting the assays, the intensity of the light emission was optimized. Results were expressed as a percentage of inhibition with respect to the blank emission using equation 5 mentioned as under, whileIC Co $_{50}$ (representing 50\% reduction) was calculated from the linear regression analysis.

$\mathrm{I}_{\text {luminescence }}(\%)==\mathrm{Lc}, \mathrm{t}-\mathrm{Ls}, \mathrm{t} \mathrm{Lc}, \mathrm{t} \times 100$

(5)

Where $t$ represents the time of measurements $(1 \mathrm{~h}$, in the acute assay) and $(20 \mathrm{~h}$, in the chronic assay), Iluminescence is the inhibition percentage, $L_{c, t,}$ and $L_{s, t}$ is the luminescence of blank and sample emission at $t$ hour respectively.

\subsection{Mineral Analysis}

The mineral composition was assessed, as reported by [23]. One gram of Oven-dried sample of (peel and pulp) was taken in digestion flask (Pyrex) having $5 \mathrm{ml}$ of absolute $\mathrm{H}_{2} \mathrm{SO}_{4}$. The flasks were heated at hotplate (Jenway, 1000, Barloworld Scientific Ltd, UK) at $80{ }^{\circ} \mathrm{C}$ to $90{ }^{\circ} \mathrm{C}$ for about $60 \mathrm{~min}$, further increasing the temperature to $160{ }^{\circ} \mathrm{C}$. Meanwhile, $5 \mathrm{ml}$ of absolute $\mathrm{HNO}_{3}$ and $2 \mathrm{ml}$ of $30 \%(\mathrm{v} / \mathrm{v}) \mathrm{H}_{2} \mathrm{O}_{2}$ were mixed to the flasks and left the mixture for boiling/heating 
until a clear solution was obtained. After effervescence had faded away, the flasks were cooled for 5 min, mixed well with a small volume of deionized water and filtered through Whatman No. $42(<0.45 \mu \mathrm{m}$ Millipore $)$ filter paper. Finally, diluted to $50 \mathrm{ml}$ with deionized water. In the same way, a blank was also prepared. All analyses were carried out in triplicate on Atomic absorption spectrophotometer (Thermo electronic corporation, Cambridge, UK). Standard calibration curves were constructed for individual elements, and results expressed in $\mathrm{mg} / 100 \mathrm{~g} \mathrm{DW}$.

\subsection{Statistical analysis}

Research data results were presented as means \pm Standard Deviation (SD) having triplicate analysis $(n=3)$. One-way analysis of variance (ANOVA) with Tukey's honestly significant difference (HSD) test was carried out to evaluate the significance of differences between means using the R-Studio software v.3.6.3 at a significance level of $P<0.05$. Pearson correlation coefficient $(r)$ was used to investigate the relationship between total phenolics and antioxidant assays at a significance level of $\mathrm{P}<0.01$ and 0.05 . Multivariate analysis in terms of Principle component analysis was carried out on the combined TFC, TPC, antioxidant activities, mineral composition and BL assay using the R-Studio software v.3.6.3.

\section{RESULTS}

\subsection{Moisture content and dry matter}

Analytical findings for the moisture content (MC), dry matter content (DMC) and extraction yield of the peel and pulp of the varieties examined are provided in Table 1. The significantly (P $<0.05)$ higher DMC and lower MC were noted in the peel tissues compared to the pulp within all studied varieties. Golden Delicious peel $(26.30 \%)$ had higher DM content, whereas the lowest values noted in the peel $(21.5 \%)$ of Katja variety.

Table 1: Extraction yield, moisture content and dry matter content of apples commonly grown in Balochistan.

\begin{tabular}{|c|c|c|c|c|}
\hline Varieties & Tissue Used & $\begin{array}{l}\text { sture } \\
\text { tent }(\%)\end{array}$ & $\begin{array}{l}\text { y Matter } \\
\text { ontent (\%) }\end{array}$ & $\begin{array}{l}\text { Extraction } \\
\text { Yield (\%) }\end{array}$ \\
\hline \multirow[t]{2}{*}{ Amri } & Peel & $75.11 \pm 0.04^{\mathrm{bc}}$ & $24.89 \pm 0.03^{\mathrm{ab}}$ & $\begin{array}{l}25.41 \\
0.96^{\mathrm{b}}\end{array}$ \\
\hline & Pulp & $83.13 \pm 0.27^{\mathrm{d}}$ & $16.87 \pm 0.27^{b}$ & $\begin{array}{l}21.34 \\
0.53^{\text {ab }}\end{array}$ \\
\hline \multirow[t]{2}{*}{ Golden Delicious } & Peel & $73.73 \pm 0.37^{\mathrm{c}}$ & $26.30 \pm 0.37^{\mathrm{a}}$ & $\begin{array}{l}31.14 \\
1.23^{\mathrm{a}}\end{array}$ \\
\hline & Pulp & $82.22 \pm 0.15^{\mathrm{e}}$ & $17.78 \pm 0.15^{\mathrm{a}}$ & $\begin{array}{l}22.86 \\
0.76^{\mathrm{a}}\end{array}$ \\
\hline Katja & Peel & $78.46 \pm 0.65^{\mathrm{a}}$ & $21.50 \pm 0.65^{\mathrm{c}}$ & 28.91 \\
\hline
\end{tabular}


Vol. 06, No. 06; 2021

ISSN: $2456-8643$

\begin{tabular}{|c|c|c|c|c|}
\hline & & & & $1.47^{\mathrm{ab}}$ \\
\hline & Pulp & $86.93 \pm 0.42^{\mathrm{a}}$ & $13.07 \pm 0.42^{\mathrm{e}}$ & $\begin{array}{l}14.22 \\
1.71^{\mathrm{d}}\end{array}$ \\
\hline Mashadi & Peel & $75.93 \pm 0.18^{\mathrm{b}}$ & $24.11 \pm 0.17^{\mathrm{b}}$ & $\begin{array}{l}28.09 \\
0.95^{\mathrm{ab}}\end{array}$ \\
\hline & Pulp & $84.69 \pm 0.10^{c}$ & $15.31 \pm 0.10^{\mathrm{c}}$ & $\begin{array}{l}19.44 \\
0.67^{\mathrm{bc}}\end{array}$ \\
\hline Red Delicious & Pell & $76.60 \pm 1.00^{\mathrm{b}}$ & $23.40 \pm 0.99^{\mathrm{b}}$ & $\begin{array}{l}31.18 \\
2.03^{\mathrm{a}}\end{array}$ \\
\hline & Pulp & $85.49 \pm 0.04^{\mathrm{b}}$ & $14.51 \pm 0.04^{\mathrm{d}}$ & $\begin{array}{l}17.58 \\
0.06^{\mathrm{c}}\end{array}$ \\
\hline
\end{tabular}

\subsubsection{Extraction yield}

The data observed for extraction yield was partially significant $(\mathrm{P}<0.05)$ for the peel and pulp extracts among studied apple varieties. Among the peels of studied varieties, a maximum yield of $31.18 \%$ was observed for the Red Delicious peel. In contrast, in the pulps, the lowest yield of $14.22 \%$ was noted for Katja pulp (Table 1).

\subsubsection{Total phenolic contents}

As evident from Figure 1. TPCs (mg GAE/100 g) of apple peel and pulp extracts varied significantly $(\mathrm{P}<0.05)$ between the varieties examined. In the peels, the highest values were observed in the peel of Red Delicious (3021.8) that was followed by Golden Delicious (2789.3). 


\section{Peel aulp}

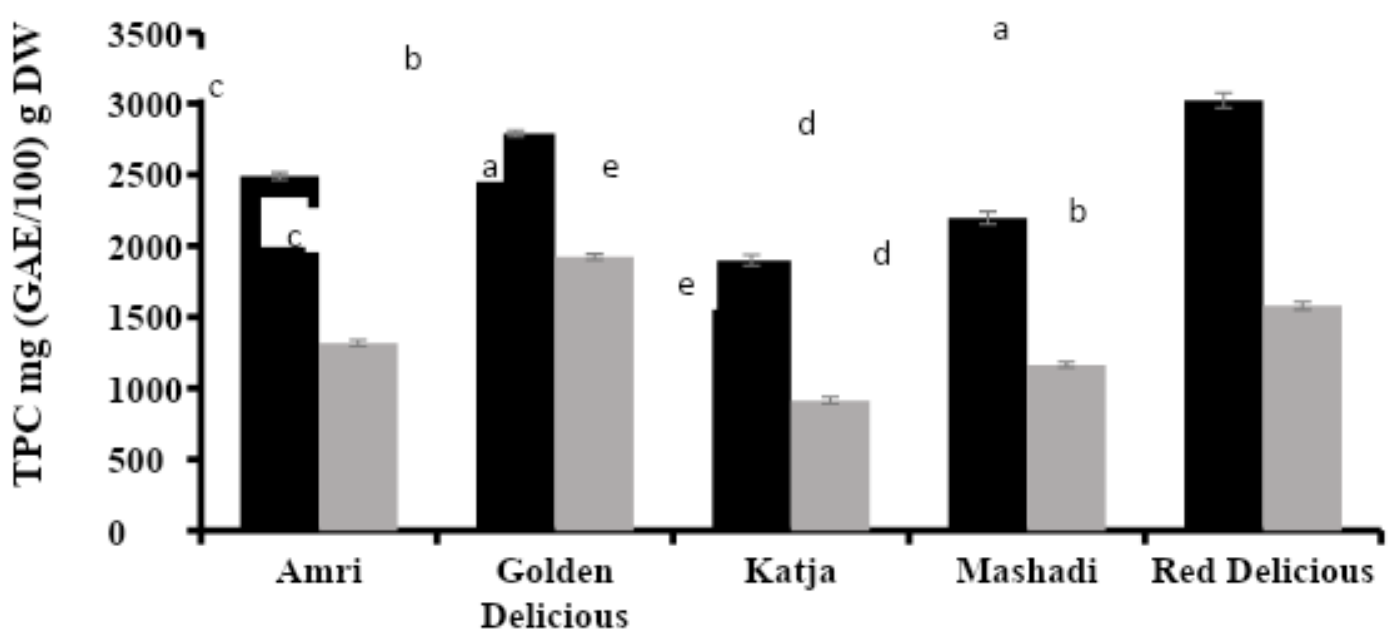

Varieties

Figure 1: TPCs of five apple varieties of peel and pulp extracts. Bars show mean $\pm \mathrm{SD},(n=3)$. Different letters indicate significant differences while the same letters denote that samples are not significantly different from one another at $\mathrm{P}<0.05$.

Whereas of the pulps, Golden Delicious apples possessed the higher TP values of 1922.1 mg GAE/100 g, followed by Red Delicious (1579.0), Amri (1316.9), and Mashadi (1164.2) apples. Nonetheless, the lowest values were observed in the pulp of Katja (913.5 \pm 23.9$)$ apples.

\subsection{Total flavonoid contents}

The results revealed that TFC values significantly differed at $\mathrm{P}<0.05$ between apple varieties as shown in Figure 2. The maximum concentrations were observed in the Red Delicious peel (2484.6) followed by Golden Delicious (2020.2). Whereas in the case of pulps, TFC were found to be rich in Golden Delicious 1387.7 variety that is followed by Red Delicious (1242.5), Amri (1077.2), Mashadi (929.1). However, the lowest values were observed in the pulp extracts of Katja (860.7) apples. The TFC trended to be maximum in peels than the pulp extracts in the studied apple varieties. 


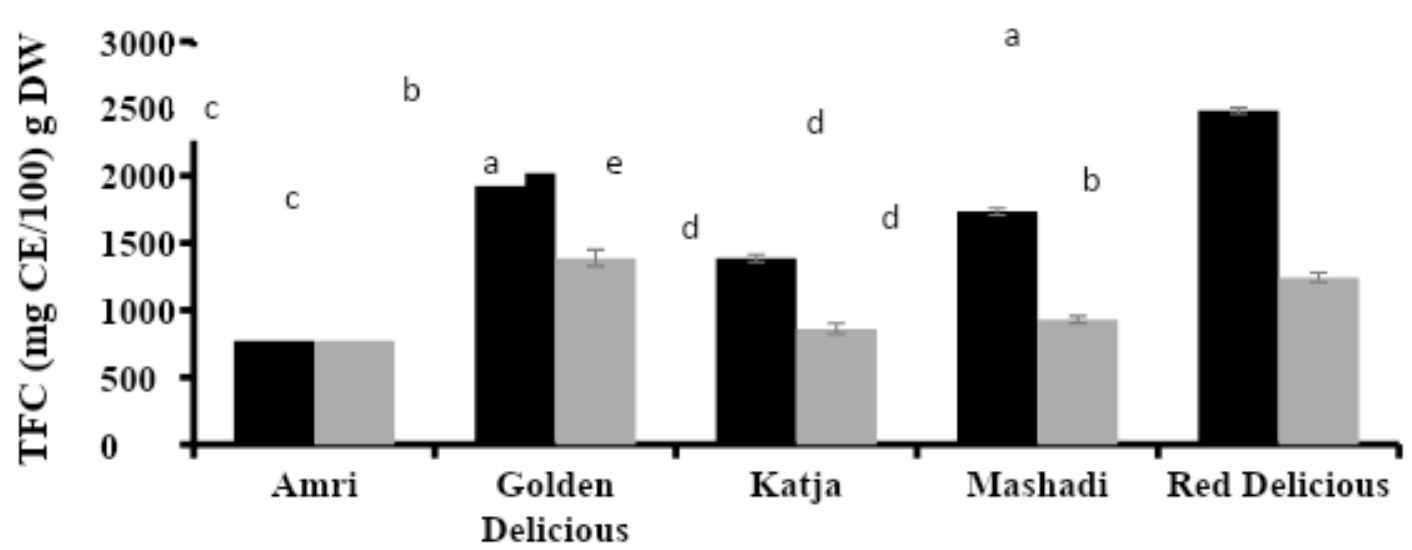

Varieties

Figure 2: TFCs of five apple varieties of peel and pulp extracts. Bars show mean $\pm \mathrm{SD},(n=3)$. Different letters indicate significant differences while the same letters denote that samples are not significantly different from one another at $\mathrm{P}<0.05$.

\subsubsection{Assessment of AoA in apple peel and pulp extracts}

Table 2 summarizes the findings of the four assay methods in terms of $\mathrm{IC}_{50} \mu \mathrm{g} / \mathrm{mL}$ of the peel and the pulp extracts of apple varieties. For HPS, DPPH, FRAP, and TAC, there were significant differences between varieties $(\mathrm{P}<0.05)$. In the case of peels, in DPPH assay, best $\mathrm{IC}_{50}$ values were possessed by Red Delicious peel $(42.55 \mu \mathrm{g} / \mathrm{mL})$, followed by Golden Delicious (52.49 $\mu \mathrm{g} / \mathrm{mL})$ Amri $(72.26 \mu \mathrm{g} / \mathrm{mL})$ Mashadi $(98.70 \mu \mathrm{g} / \mathrm{mL})$ and Katja $(111.84 \mu \mathrm{g} / \mathrm{mL})$. Whereas in the pulps, the minimum values were recorded in Golden Delicious $(73.51 \mu \mathrm{g} / \mathrm{mL})$, preceded by Red Delicious $(87.01 \mu \mathrm{g} / \mathrm{mL})$, Amri $(137.75 \mu \mathrm{g} / \mathrm{mL})$, Mashadi $(146.26 \mu \mathrm{g} / \mathrm{mL})$ and Katja $(153.90$ $\mu \mathrm{g} / \mathrm{mL})$. However, the activity of peel extracts were inferior to AA $(11.18 \mu \mathrm{g} / \mathrm{mL})$ and Trolox $(16.57 \mu \mathrm{g} / \mathrm{mL})$.

Table 2: Comparison of AoA of peel and pulp extracts and standard compounds assessed by DPPH, HPS and TAC assays (IC50 $\mu \mathrm{g} / \mathrm{ml})$.

\begin{tabular}{|c|c|c|c|c|c|}
\hline \multicolumn{6}{|c|}{ Antioxidant index } \\
\hline & Amri & $\begin{array}{l}\text { Golden } \\
\text { Delicious } \\
\end{array}$ & Katja & Mashadi & $\begin{array}{l}\text { Red } \\
\text { Delicious }\end{array}$ \\
\hline \multicolumn{6}{|c|}{ DPPH } \\
\hline Peel & $\begin{array}{l}72.26 \pm 0.9 \\
\mathrm{c}\end{array}$ & $52.49 \pm 0.8^{d}$ & ${ }_{a}^{111.84} \pm 0.3$ & $98.70 \pm 0.3^{b}$ & $42.55 \pm 1.6^{\mathrm{e}}$ \\
\hline Pulp & $137.75 \pm 2.5$ & $73.51 \pm 3.0^{\mathrm{d}}$ & $153.90 \pm 4.6$ & $146.26 \pm 4.6^{\mathrm{a}}$ & $87.01 \pm 2.1^{\mathrm{c}}$ \\
\hline
\end{tabular}


Vol. 06, No. 06; 2021

ISSN: $2456-8643$

\begin{tabular}{|c|c|c|c|c|c|c|}
\hline & b & & $\mathrm{a}$ & & & \\
\hline Ascorbic acid & $11.18 \pm 0.80$ & & & & & \\
\hline Trolox & $16.57 \pm 0.56$ & & & & & \\
\hline \multicolumn{7}{|l|}{$H P S$} \\
\hline Peel & $\begin{array}{l}355.72 \quad \pm \\
0.83^{\mathrm{c}}\end{array}$ & $388.40 \pm 0.86 \mathrm{a}$ & $\begin{array}{l}386.01 \\
2.04^{\mathrm{a}}\end{array}$ & \pm & $\begin{array}{l}372.00 \pm 3.75 \\
\mathrm{~b}\end{array}$ & $\begin{array}{l}327.40 \pm 3.32 \\
\mathrm{~d}\end{array}$ \\
\hline Pulp & $\begin{array}{l}370.22 \quad \pm \\
0.92^{\mathrm{d}}\end{array}$ & $344.06 \pm 1.40 \mathrm{e}$ & $\begin{array}{l}450.84 \\
2.23 \mathrm{a}\end{array}$ & \pm & $\begin{array}{l}425.24 \pm 1.15 \\
\mathrm{~b}\end{array}$ & $\begin{array}{l}403.22 \pm 1.43 \\
c\end{array}$ \\
\hline Ascorbic acid & $\begin{array}{l}285.73 \\
0.33\end{array}$ & & & & & \\
\hline $\begin{array}{l}\text { Alpha- } \\
\text { tocopherol } \\
\boldsymbol{T A C}\end{array}$ & $\begin{array}{l}195.65 \quad \pm \\
0.53\end{array}$ & & & & & \\
\hline Peel & $\begin{array}{ll}42.52 & \pm \\
5.33 b^{c} & \end{array}$ & $37.99 \pm 3.34^{\mathrm{cd}}$ & $\begin{array}{l}62.89 \pm 4.0 \\
\mathrm{a}\end{array}$ & & $\underset{\mathrm{ab}}{52.17 \pm 4.23}$ & $\begin{array}{l}26.83 \\
d\end{array}$ \\
\hline Pulp & $\underset{\mathrm{ab}}{58.19} \pm 6.34$ & $56.42 \pm 6.64^{b}$ & $76.42 \pm 4.8$ & & $\underset{\mathrm{ab}}{71.93} \pm 6.67$ & $\begin{array}{l}63.91 \pm 9.04 \\
\mathrm{ab}\end{array}$ \\
\hline $\begin{array}{l}\text { Ascorbic acid } \\
\text { Quercetin } \\
\boldsymbol{F R A P}\end{array}$ & $\begin{array}{l}16.97 \pm 3.91 \\
7.41 \pm 2.17\end{array}$ & & & & & \\
\hline Peel & $\begin{array}{l}89.03 \pm 0.27 \\
\mathrm{c}\end{array}$ & $77.82 \pm 0.44^{\mathrm{d}}$ & $\begin{array}{l}103.29 \\
0.49^{\mathrm{a}}\end{array}$ & \pm & $96.93 \pm 1.26^{b}$ & $e_{e}^{71.06 \pm 0.51}$ \\
\hline Pulp & $\begin{array}{l}163.35 \\
1.11^{\mathrm{c}}\end{array}$ & $126.11 \pm 0.87^{\mathrm{e}}$ & $\begin{array}{l}192.22 \\
1.57^{\mathrm{a}}\end{array}$ & \pm & $181.82 \pm 2.30$ & $141.33 \pm 0.59$ \\
\hline $\begin{array}{l}\text { Ascorbic acid } \\
\text { Catechin }\end{array}$ & $\begin{array}{l}70.32 \pm 0.55 \\
65.55 \pm 0.24\end{array}$ & & & & & \\
\hline
\end{tabular}

All values are mean $\pm \mathrm{SD}(n=3)$. Statistically significant differences $(\mathrm{P}<0.05)$ are denoted by different superscript letters within each line. 'Peel/pulp' shows the AoA ratio in the peel to that in the pulp. DPPH, HPS, TAC and FRAP represent radical scavenging assay, hydrogen peroxide scavenging assay, total antioxidant capacity assay, ferric reducing antioxidant power, respectively.

In the HPS assay, of the peels, the lowest and highest $\mathrm{IC}_{50}$ values were measured in the peels of Red Delicious (327.40 $\mu \mathrm{g} / \mathrm{mL})$ and Mashadi $(388.40 \mu \mathrm{g} / \mathrm{mL})$, respectively.

Whereas, in the pulp extracts minimum $\mathrm{IC}_{50}$ values were noted in Golden Delicious (344.06 $\mu \mathrm{g} / \mathrm{mL}$ ) pulp followed by Amri $(370.22 \mu \mathrm{g} / \mathrm{mL}$ ), Red Delicious (403.22 $\mu \mathrm{g} / \mathrm{mL}$ ), Mashadi $(425.24 \mu \mathrm{g} / \mathrm{mL})$ and Katja $(450.84 \mu \mathrm{g} / \mathrm{mL})$ pulp. Nonetheless, the HPS AoA of AA $(285.73 \mu \mathrm{g} / \mathrm{mL})$ and alpha-tocopherol $(195.65 \mu \mathrm{g} / \mathrm{mL})$ were superior to all studied extracts. Furthermore, the ratio of AoA in the peel to that in the pulp in the HPS assay ranged from 0.81 to 1.08. Regarding the results of TAC assay, in the pulp extracts, the lowest $\mathrm{IC}_{50}$ values of TAC assay were noted for Golden Delicious $(56.42 \mu \mathrm{g} / \mathrm{mL})$ variety, followed by in the pulps of Amri $(58.19 \mu \mathrm{g} / \mathrm{mL})$, Red Delicious (63.91 $\mu \mathrm{g} / \mathrm{mL})$, Mashadi $(71.93 \mu \mathrm{g} / \mathrm{mL})$ and Katja $(76.42 \mu \mathrm{g} / \mathrm{mL})$. On the other hand, the TAC activity in the peel extracts was maximum with the lowest $\mathrm{IC}_{50}$ in 
the Red Delicious peel (26.83) preceded by Golden Delicious $(37.99 \mu \mathrm{g} / \mathrm{mL})$, Amri $(42.52$ $\mu \mathrm{g} / \mathrm{mL})$, Mashadi $(52.17 \mu \mathrm{g} / \mathrm{mL})$ and Katja $(62.89 \mu \mathrm{g} / \mathrm{mL})$ apples.

Nonetheless, TAC of AA $(16.97 \mu \mathrm{g} / \mathrm{mL})$ and QU $(7.41 \mu \mathrm{g} / \mathrm{mL})$ was superior to the peel and pulp extracts. The ratio of AoA in the peel to that in the pulp in TAC assay ranged from 0.43 to 0.82 . Using FRAP assay a very good reducing activity with low $\mathrm{IC}_{50}$ values was noted in the peel extracts than the pulp extracts. In the peels, strong and weak activity was observed in Red Delicious $(71.06 \mu \mathrm{g} / \mathrm{mL})$ and Katja $(103.29 \mu \mathrm{g} / \mathrm{mL})$ apples. In contrast, maximum and minimum activity in the pulp extracts was exhibited by Golden Delicious $(126.11 \mu \mathrm{g} / \mathrm{mL})$ and Katja $(192.22 \mu \mathrm{g} / \mathrm{mL})$ varieties, respectively. The activity of the Red Delicious peel was slightly lower than that of AA $(70.32 \mu \mathrm{g} / \mathrm{mL})$. Additionally, the ratio of AoA in the peel to that in the pulp in the FRAP assay ranged from 0.50 to 0.62 .

\subsection{Bioluminescence (BL) assay}

The results regarding the acute and chronic biotoxicity assay of pulp and peel extracts of five studied varieties of apple are shown in Table 3 and 4, respectively. There was no bacterial luminescence inhibition in the acute assay of pulp and peel extracts of studied apple varieties performed at room temperature at the studied concentrations as compared to the blank; it increased bacterial luminescence.

Table 3: Percentage inhibition of acute BL toxicity assay of pulp and peel extracts of apple varieties against $\mathrm{V}$. logei bacteria.

\begin{tabular}{|lllll|}
\hline Fruit part & \multicolumn{4}{c|}{ Luminescence Inhibition (\%) (after 1 h) } \\
\hline \multirow{4}{*}{ Peel } & Varieties & $\begin{array}{l}\mathbf{1 : 1 0} \\
\text { Dilution }\end{array}$ & $\begin{array}{l}\text { 1:100 } \\
\text { Dilution }\end{array}$ & $\begin{array}{l}\text { 1:1000 } \\
\text { Dilution }\end{array}$ \\
& Amri & $-18.65 \pm 33.26^{\mathrm{a}}$ & $-29.13 \pm 68.76^{\mathrm{a}}$ & $-4.04 \pm 33.40^{\mathrm{a}}$ \\
& Golden Delicious & $-9.84 \pm 34.03^{\mathrm{a}}$ & $-22.59 \pm 43.46^{\mathrm{a}}$ & $-24.85 \pm 41.89^{\mathrm{a}}$ \\
& Katja & $-46.72 \pm 49.31^{\mathrm{b}}$ & $-37.20 \pm 45.96^{\mathrm{a}}$ & $-17.94 \pm 33.73^{\mathrm{a}}$ \\
& Mashadi & $-125.07 \pm 69.28^{\mathrm{b}}$ & $-108.09 \pm 54.85^{\mathrm{b}}$ & $-103.80 \pm 51.44^{\mathrm{b}}$ \\
& Red Delicious & $-47.63 \pm 33.25^{\mathrm{a}}$ & $-54.78 \pm 48.34^{\mathrm{a}}$ & $-24.06 \pm 36.77^{\mathrm{a}}$ \\
& Amri & $-42.17 \pm 35.85^{\mathrm{a}}$ & $-90.78 \pm 66.91^{\mathrm{ab}}$ & $-25.01 \pm 42.19^{\mathrm{a}}$ \\
& Golden Delicious & $-58.35 \pm 46.58^{\mathrm{a}}$ & $-62.17 \pm 50.94^{\mathrm{a}}$ & $-39.78 \pm 43.05^{\mathrm{a}}$ \\
& Katja & $-52.54 \pm 46.07^{\mathrm{a}}$ & $-58.18 \pm 52.72^{\mathrm{a}}$ & $-26.16 \pm 37.88^{\mathrm{a}}$ \\
& Mashadi & $-83.55 \pm 44.72^{\mathrm{a}}$ & $-64.67 \pm 50.90^{\mathrm{a}}$ & $-65.46 \pm 55.11^{\mathrm{b}}$
\end{tabular}


Vol. 06, No. 06; 2021

ISSN: $2456-8643$

$$
\text { Red Delicious } \quad-12.49 \pm 38.53^{\mathrm{a}} \quad-42.82 \pm 48.76^{\mathrm{a}} \quad-13.58 \pm 32.14^{\mathrm{a}}
$$

All values are mean $\pm \mathrm{SD}(n=3)$. Statistically significant differences $(\mathrm{P}<0.05)$ are denoted by different superscript letters within each column.

Therefore, none of the extracts from either of the peel or pulp of studied apple varieties were capable to stop the bacterial light at studied concentrations during given contact time of 60 min in acute toxicity test. Hence it was not possible to calculate $\mathrm{IC}_{50}$.

While at less concentrated dilutions in chronic toxicity assay, among the studied apple varieties only the peel extracts of Red Delicious and Golden Delicious were capable of bacterial BL inhibition at all studied concentrations with $\mathrm{IC}_{50}$ of 1.12 and $1.77 \mathrm{mg} / \mathrm{mL}$, respectively.

Table 4: Percentage inhibition and $\mathrm{IC}_{50}(\mathrm{mg} / \mathrm{mL})$ of chronic bioluminescence toxicity assay of pulp and peel extracts of apple varieties against $\mathrm{V}$. logei bacteria.

\begin{tabular}{|c|c|c|c|c|c|c|c|}
\hline $\begin{array}{l}\text { Fruit } \\
\text { part }\end{array}$ & & Luminescenc & Inhibition (\% & b) (a & fter $20 \mathrm{~h}$ ) & & \\
\hline & Varieties & $\begin{array}{l}\text { 1:5 } \\
\text { Dilution }\end{array}$ & $\begin{array}{l}\text { 1:50 } \\
\text { Dilution }\end{array}$ & & $\begin{array}{l}\text { 1:500 } \\
\text { Dilution }\end{array}$ & & $\begin{array}{l}\mathrm{IC}_{50} \\
(\mathrm{mg} / \mathrm{mL})\end{array}$ \\
\hline \multirow[t]{3}{*}{ Peel } & Amri & $\begin{array}{ll}90.03 & \pm \\
15.90^{\mathrm{a}} & \pm\end{array}$ & $\begin{array}{l}-304.56 \\
239.3^{\text {ab }}\end{array}$ & \pm & $\begin{array}{l}-325.90 \\
311.6^{\mathrm{a}}\end{array}$ & \pm & \\
\hline & $\begin{array}{l}\text { Golden } \\
\text { Delicious }\end{array}$ & $98.57 \pm 1.52^{\mathrm{a}}$ & $50.59 \pm 5.2^{\mathrm{a}}$ & & $25.61 \pm 4.0^{\mathrm{a}}$ & & $1.77 \pm 0.03^{\mathrm{a}}$ \\
\hline & Katja & $95.91 \pm 2.91^{\mathrm{a}}$ & $28.66 \pm 55.2^{\mathrm{a}}$ & & $\begin{array}{l}-385.91 \\
332.1^{\mathrm{a}}\end{array}$ & \pm & \\
\hline \multirow{5}{*}{ Pulp } & Mashadi & $\begin{array}{l}68.48 \\
54.40^{\mathrm{a}}\end{array}$ & $\begin{array}{l}-333.92 \\
190.2^{\mathrm{b}}\end{array}$ & \pm & $\begin{array}{l}-358.58 \\
347.0^{\mathrm{a}}\end{array}$ & \pm & \\
\hline & Red Delicious & $99.99 \pm 0.00^{\mathrm{a}}$ & $68.50 \pm 4.0^{\mathrm{a}}$ & & $47.88 \pm 8.3^{\mathrm{a}}$ & & $1.12 \pm 0.28^{\mathrm{b}}$ \\
\hline & Amri & $93.71 \pm 8.59^{\mathrm{a}}$ & $\begin{array}{l}-425.64 \\
334.4^{\mathrm{a}}\end{array}$ & \pm & $\begin{array}{l}-355.56 \\
345.6^{a}\end{array}$ & \pm & \\
\hline & Golden & 83.64 & - 644.99 & \pm & -318.71 & \pm & \\
\hline & Delicious & $20.73^{\mathrm{a}}$ & $488.0^{\mathrm{a}}$ & & $356.3^{\mathrm{a}}$ & & \\
\hline & Katja & $96.87 \pm 2.98^{\mathrm{a}}$ & $-304.47 \pm 69$ & & $\begin{array}{l}-360.99 \\
398.7^{\mathrm{a}}\end{array}$ & \pm & \\
\hline
\end{tabular}




\begin{tabular}{|c|c|c|c|c|}
\hline Mashadi & $93.79 \pm 7.02^{\mathrm{a}}$ & $\begin{array}{l}-546.07 \\
375.0^{\mathrm{a}}\end{array}$ & & $\begin{array}{l}-377.67 \\
374.0^{\mathrm{a}}\end{array}$ \\
\hline Red Delicious & $99.40 \pm 0.75^{\mathrm{a}}$ & $\begin{array}{l}-846.80 \\
569.8^{\mathrm{a}}\end{array}$ & \pm & $\begin{array}{l}-296.06 \\
350.8^{\mathrm{a}}\end{array}$ \\
\hline
\end{tabular}

All values are mean $\pm \mathrm{SD}(n=3)$. Statistically significant differences $(\mathrm{P}<0.05)$ are denoted by different superscript letters within each column.

\subsection{Mineral Composition of apple peel and pulp}

The mineral composition ( $\mathrm{mg} / 100 \mathrm{~g} \mathrm{DW})$ of peel and pulp samples of apricot varieties is shown in Table 5 and 6, respectively. The results obtained revealed a significant trend $(p<0.05)$ among the apple varieties. The varieties tested contained higher concentrations of $\mathrm{K}$ followed by $\mathrm{Ca}, \mathrm{Na}$ and $\mathrm{Fe}$.

Table 5: Mineral contents in the peel and pulp of apple widely cultivated in Balochistan.

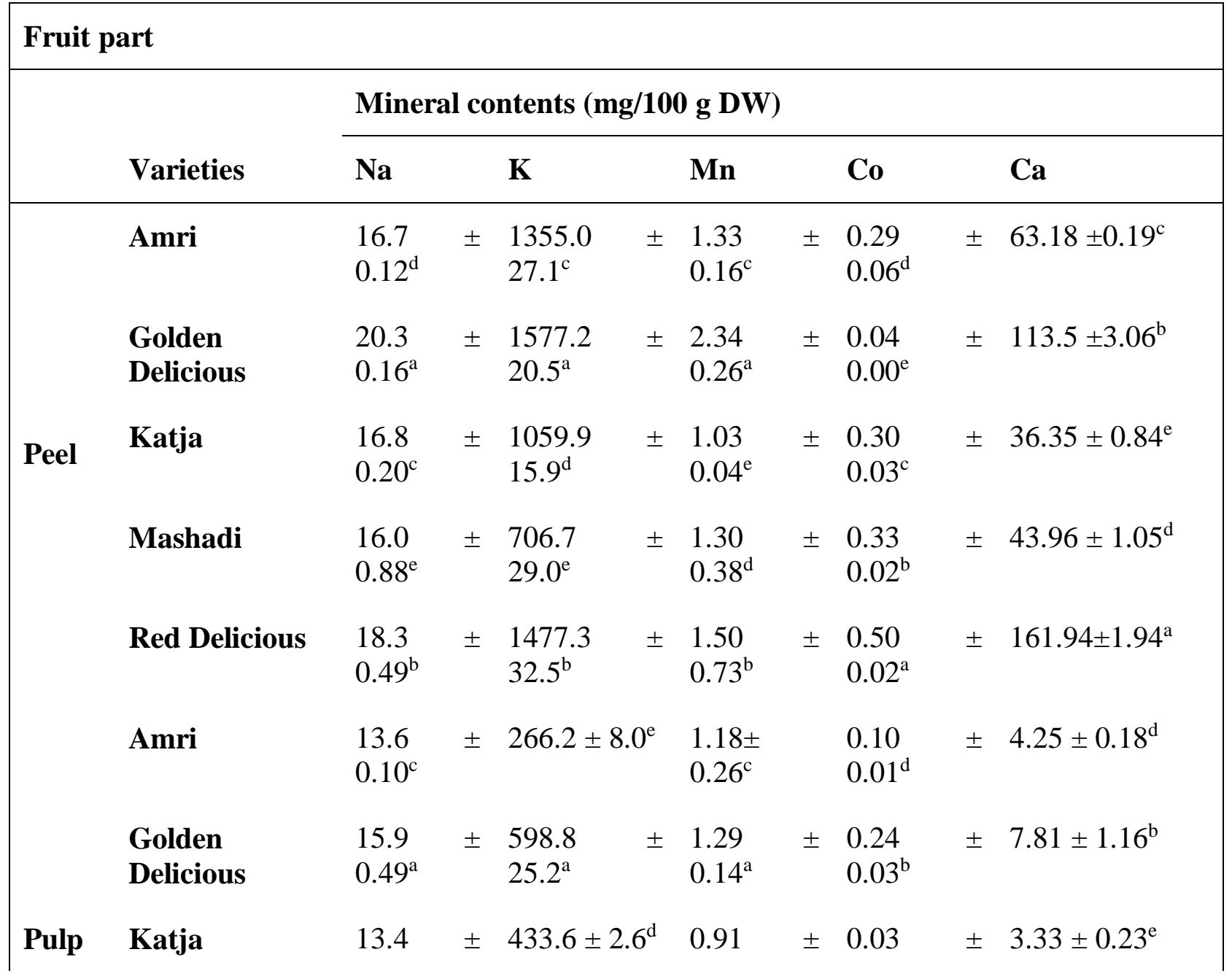


Vol. 06, No. 06; 2021

ISSN: $2456-8643$

\begin{tabular}{|c|c|c|c|c|c|c|c|}
\hline & $0.21^{\mathrm{d}}$ & & & $0.02^{\mathrm{e}}$ & & $0.02^{\mathrm{e}}$ & \\
\hline Mashadi & $\begin{array}{l}12.3 \\
0.15^{\mathrm{e}}\end{array}$ & \pm & $459.5 \pm 7.4^{\mathrm{c}}$ & $\begin{array}{l}1.03 \\
0.04^{\mathrm{d}}\end{array}$ & \pm & $\begin{array}{l}0.41 \\
0.04^{\mathrm{a}}\end{array}$ & $\pm 5.8 \pm 1.37^{\mathrm{c}}$ \\
\hline Red Delicious & $\begin{array}{l}13.6 \\
0.08^{b}\end{array}$ & \pm & $\begin{array}{l}532.1 \\
19.7^{\mathrm{b}}\end{array}$ & $\begin{array}{l}1.24 \\
0.16^{\mathrm{b}}\end{array}$ & \pm & $\begin{array}{l}0.18 \\
\pm 0.02^{\mathrm{c}}\end{array}$ & $16.79 \pm 2.57^{\mathrm{a}}$ \\
\hline
\end{tabular}

All values are mean $\pm \mathrm{SD}(n=3)$. Statistically significant differences $(\mathrm{P}<0.05)$ are denoted by different superscript letters within each column, DW: Dry weight.

The measured concentrations of $\mathrm{K}, \mathrm{Ca}, \mathrm{Na}, \mathrm{Fe}, \mathrm{Mn}, \mathrm{Co}, \mathrm{Cu}, \mathrm{Cd}$ and $\mathrm{Ni}$ ranged from 706.67 to $1577.15,36.35$ to $161.94,15.99$ to $20.29,1.74$ to $5.04,1.03$ to $2.34,0.04$ to $0.50,0.21$ to 0.41 , 0.002 to 0.005 and 0.14 to $0.23 \mathrm{mg} / 100 \mathrm{~g} \mathrm{DW}$, respectively in the samples of peel. Whereas 266.18-598.83, 3.33-16.79, 12.34-15.88, 1.59-4.99, 0.91-1.29, 0.03-0.24, 0.07-0.18, 0.001-0.005 and $0.03-0.07 \mathrm{mg} / 100 \mathrm{~g} \mathrm{DW}$, respectively in the samples of pulp.

Table 6: Trace mineral concentrations in the peel and pulp of apple widely cultivated in Balochistan.

\begin{tabular}{|c|c|c|c|c|c|}
\hline \multicolumn{6}{|c|}{ Fruit part } \\
\hline & \multirow[b]{2}{*}{ Varieties } & \multicolumn{4}{|c|}{ Mineral contents (mg/100 g DW) } \\
\hline & & $\mathbf{C u}$ & $\mathbf{F e}$ & Cd & $\mathbf{N i}$ \\
\hline \multirow{5}{*}{ Peel } & Amri & $0.24 \pm 0.03^{c}$ & $3.47 \pm 0.03^{\mathrm{c}}$ & $0.002 \pm 0.01^{\mathrm{d}}$ & $0.19 \pm 0.03^{\mathrm{c}}$ \\
\hline & Golden Delicious & $0.27 \pm 0.04^{\mathrm{b}}$ & $5.04 \pm 0.01^{\mathrm{a}}$ & $0.004 \pm 0.02^{\mathrm{b}}$ & $0.23 \pm 0.06^{\mathrm{a}}$ \\
\hline & Katja & $0.21 \pm 0.06^{\mathrm{d}}$ & $1.74 \pm 0.03^{\mathrm{e}}$ & $0.004 \pm 0.01^{\mathrm{b}}$ & $0.15 \pm 0.04^{\mathrm{d}}$ \\
\hline & Mashadi & $0.21 \pm 0.04^{\mathrm{d}}$ & $2.08 \pm 0.05^{\mathrm{d}}$ & $0.003 \pm 0.02^{\mathrm{c}}$ & $0.14 \pm 0.03^{\mathrm{e}}$ \\
\hline & Red Delicious & $0.41 \pm 0.07^{\mathrm{a}}$ & $4.01 \pm 0.05^{\mathrm{b}}$ & $0.005 \pm 0.02^{\mathrm{a}}$ & $0.22 \pm 0.01^{\mathrm{b}}$ \\
\hline \multirow{5}{*}{ Pulp } & Amri & $0.13 \pm 0.02^{\mathrm{c}}$ & $2.81 \pm 0.05^{\mathrm{c}}$ & $0.001 \pm 0.01^{\mathrm{d}}$ & $0.03 \pm 0.02^{\mathrm{a}}$ \\
\hline & Golden Delicious & $0.18 \pm 0.02^{\mathrm{a}}$ & $4.99 \pm 0.25^{\mathrm{a}}$ & $0.005 \pm 0.02^{\mathrm{a}}$ & $0.07 \pm 0.02^{\mathrm{b}}$ \\
\hline & Katja & $0.07 \pm 0.03^{\mathrm{e}}$ & $1.59 \pm 0.03^{\mathrm{e}}$ & $0.003 \pm 0.01^{\mathrm{b}}$ & ND \\
\hline & Mashadi & $0.08 \pm 0.05^{\mathrm{d}}$ & $1.97 \pm 0.12^{\mathrm{d}}$ & $0.001 \pm 0.01^{\mathrm{d}}$ & ND \\
\hline & Red Delicious & $0.16 \pm 0.06^{\mathrm{b}}$ & $3.38 \pm 0.11^{\mathrm{b}}$ & $0.002 \pm 0.01^{\mathrm{c}}$ & $0.07 \pm 0.03^{b}$ \\
\hline
\end{tabular}

All values are mean $\pm S D(n=3)$. Statistically significant differences $(P<0.05)$ are denoted by 
superscript letters within each column, DW: Dry weight, ND: Not Detected.

\section{DISCUSSION}

According to the best of our knowledge, this was the first study undertaken to investigate some physical properties, AoA, phenolics, flavonoids, mineral contents, and BL toxicity assays in the peel and pulp of six apple varieties. These varieties are commonly grown in northern regions of the province of Balochistan, Pakistan. The fruits of these varieties varied in texture, size, taste, aroma and flavor. MC assessment is among the most significant and commonly used parameters that dramatically influences the concentration and composition of phytochemicals in fruits, vegetables, seeds and grains [24]. In this study the mean MC in apple peel and pulp was 75.97\% and $84.49 \%$, it is likely that peel is less hydrated than the pulp. These results are coincident with the range of (76.69-88.37\%) published by Campeanu, Neata, \& Darjanschi, [25] and less than those stated by Rosnah, Wong, Noraziah, \& Osman, [26]. According to the (food and agriculture organization [FAO], 1993), vegetables contain 90-96 percent water, while fruit has an average water content of 80-90 percent. Nevertheless, fruits of lower MC have good shelf life while the high moisture content in the samples indicated that they possess perishability [27].

On the other hand, Interest in DM is motivated by the need for objective quality measurement based on fundamental fruit biology, but also representing potential taste and allowing more reliable preharvest, harvesting and postharvest evaluation of fruit [28]-[30]. In this study a higher DM content was noted in the peel tissues compared to the pulp within all studied varieties. In this context, Golden Delicious and Amri varieties would be better for commercial purposes because apart from the fruit's texture, consumers preferred the fruits with higher dry matter [30]. Obtained results of the DM content in the apple peel and the pulp agree with the data reported by [13]. While the calculated DMC in apple peel was higher than those published by Vieira et al. [31].

Nevertheless, amid many work priorities in the extraction of polyphenols, there is no single solvent that can be deemed universal since it is typically different for different plant matrices [32]. Generally, polar solvents such as ethanol, methanol, acetone and ethyl acetate, etc. are used to extract polyphenolics. In current study an almost higher extraction yield was achieved for the peels than that of the pulps, which is in line with the previous report that under same conditions higher extraction yield in peels may be attributed to the different opportunity of extractable materials, associated with the chemical composition of the various tissues under investigation[14].

It has been reported that the composition of secondary metabolites can be different in apple cultivars and the concentration of these compounds differ several folds. Other differences could be connected to pedoclimatic aspects and cultivars [33]-[35]. In this study, peel extracts showed significantly higher TPC and TFC than the pulp extracts, which can be described by the protective role of phenolic compounds [8]. They provide protection against UV-radiation, play the role of defense chemicals to averse predators and pathogens, and act as attractants in fruit dispersion [11]. Consistent with this study's findings other researchers [6], [11], [14] have also described that the polyphenol content of peel tissue was higher than other edible parts of the apple fruit. 
Of the 5 apple varieties studied, the TPC and TFC in the peel and pulp considerably varied from 1-1.6 and 1-1.2 folds and 1-1.8 and 1-1.5 folds, respectively, suggest a considerable variation in polyphenol contents is attributed to genotype. As determined in the present study, the highest TP contents in the peel of Red Delicious apples were also previously described by other researchers [7], [13]. The obtained TPC and TFC values were higher than previously recorded levels [6], [14], respectively in five and four apple cultivars of (Malus Domestica Borkh.). These differences in polyphenol contents among various investigators principally could be due to numerous reasons involving genetic factors, ripening stage, cultivar, environmental factors, growing seasons, production techniques, storage conditions and geographic territory [36]-[38]. As no proper phytosanitary treatments were applied in the orchards, a rise in phenolic content may be a plant response to stress after various types of stress were applied to the varieties [39]. Additionally, the collected varieties were fully exposed to the sunlight, which can be accounted for higher flavonoid contents [40]. Moreover, the lowest TPC and TFC in the Katja variety can be explained on the fact that old apple cultivars generally are distinguished by maximum TPCs, as new cultivars are reproduced for appealing deliciousness [41]. Among the studied apple varieties, only Katja is a new breed.

The antioxidant potential of apple peel and pulp was measured spectroscopically using DPPH, HPS, TAC and FRAP assays. Owing to the complex modes of action of antioxidants and complex sample behavior such as different polarities, functional groups, and chemical etiquettes, numerous AoA measurement assays are suggested in in-vitro antioxidant analysis. That was because, according to Opitz et al. [42], a single assay does not provide fair results as compared to a series of experiments involving different chemical reactions. Furthermore, the interactions between antioxidants and free radicals are second-order. As a result, they are affected not only by antioxidant and free radical concentrations, but also by factors such as the chemical composition of both reagents, the medium, and the reaction conditions [43]. All of these tests are easy and fast to carry out, and only involve a UV-vis spectrophotometer and a few reagents. Some researchers have discovered a connection between phytochemical contents and AoA [14], [24]. Therefore, in this study Pearson's correlation analysis (Table 6) disclosed that negative correlations between TPC and TFC assays with $\mathrm{IC}_{50}$ values of HPS, DPPH, TAC and FRAP assays, it demonstrates that the samples with substantial polyphenol content manifest lower $\mathrm{IC}_{50}$ values, agreeing that phenolics are seemed to contribute to the AoA of the extracts. Both flavonoids and phenolic acids have been proved for their reductive capacities and potent antioxidants.

Table 7: Pearson's correlation coefficients of phytochemical contents and different AO assays of peel and pulp of apples widely cultivated in Balochistan.

\section{Antioxidant index}

Coefficient correlation Pearson (r)

\begin{tabular}{|llllll|}
\cline { 2 - 4 } & TPC & TFC & IC $_{50}$ DPPH & IC $_{50}$ HPS & IC $_{50}$ TAC \\
\hline TFC & $0.965^{* *}$ & & &
\end{tabular}


these varieties. The anti-quorum sensing activity of apple peel crude extract was also reported by [52] in the C. violaceum agar diffusion test system. In this context, the quantification and identification of secondary metabolites having the anti-luminescence potential to the $V$. logei of Red Delicious and Golden Delicious peels could significantly benefit, particularly in discovering new antivirulence compounds.

Apart from phytochemicals, the information about the concentration of essential minerals is of great significance since the activity of more than one-third of all human proteins relies on them [9]. Our findings revealed that among others, $\mathrm{K}, \mathrm{Ca}, \mathrm{Na}$ and $\mathrm{Fe}$ are significant apple minerals, which are in line with [13], [14].

The major microelements in the investigated samples were $\mathrm{Na}, \mathrm{Fe}, \mathrm{Mn}, \mathrm{Cu}, \mathrm{Co}$ and $\mathrm{Ni}$. The sample type was the leading factor that affected the amounts of $\mathrm{Na}, \mathrm{K}, \mathrm{Mn}, \mathrm{Co}, \mathrm{Ca}, \mathrm{Fe}$ and $\mathrm{Cu}$. The measured concentrations of minerals were higher in the peel than the corresponding pulp tissues, which is in line with[12]-[14]. Mineral concentrations can also differ widely with cultivar [53]. However, in this study the cultivar type did not significantly affect the amounts of tested elements. In general, the peel and pulp concentrations were per cited literature [12], [13]. The iron, manganese, and copper content in our study was also higher than reported by[13]. However, they reported the highest iron and manganese content in the peels of 'Fuji' and 'Red Delicious' cultivars, respectively. This contradicts the present study findings, which could be due to the differential potential of variety to absorb ions from the soil. The cadmium content was found in the allowable limits $(0.05 \mathrm{mg} / \mathrm{kg})$ sets by [54]. The presence of heavy metals like cadmium and nickel in the pulp could be contaminated soil, whereas in the peel may be due to polluted environments.

\subsection{Principal component analysis}

The principal component analysis (PCA) is a well-known data processing technique that can be used to compress higher-dimensional data sets to lower-dimensional ones [55]. The results regarding the PCA of apple fruit are summarized in Table 8. Except for the content of $\mathrm{Ni}, \mathrm{Cd}$, and BL assays, which had marginal values, the entire data on TFC, TPC, mineral contents, and AO assays were subjected to PCA (13 total variables).

Table 8: Principal components analysis of phytochemical contents, mineral contents and AO assays of apple.

\begin{tabular}{|lccl|}
\hline Component & PC 1 & PC 2 & PC 3 \\
\hline Eigen value & 9.855 & 1.486 & 0.814 \\
Total variance (\%) & 75.80 & 11.43 & 6.26 \\
Cumulative variance (\%) & 75.80 & 87.24 & 93.50 \\
TPC & -0.316 & 0.051 & -0.050
\end{tabular}




\begin{tabular}{|lccc} 
TFC & -0.311 & 0.119 & -0.079 \\
Na & -0.292 & -0.166 & -0.250 \\
K & -0.287 & 0.002 & -0.369 \\
Ca & -0.291 & 0.094 & -0.276 \\
Mn & -0.221 & -0.391 & 0.548 \\
Cu & -0.242 & -0.456 & -0.132 \\
Co & -0.305 & 0.181 & -0.023 \\
DPPH & -0.099 & 0.729 & 0.171 \\
TAC & 0.300 & 0.071 & -0.214 \\
HPS & 0.308 & -0.036 & -0.074 \\
FRAP & 0.258 & -0.092 & -0.556 \\
\hline
\end{tabular}

Three important principal components (PCs) were found to account for over $90 \%$ of the variance in the results. With maximum $(75.80 \%)$ data variation PC 1 showed the highest data loadings for TAC assay followed (in decreasing order) by FRAP, DPPH and HPS assays respectively. PC 2 had strong loadings for the $\mathrm{Co}, \mathrm{Cu}$, and TFC assays, as well as major contributions from the DPPH and TPC assays. PC 3 showed the highest loadings in favor of Fe, Co, and the FRAP assay. The Flavonoids and phenolic contents had strong associations with the AoA assays, according to the PCA findings.

\section{CONCLUSION}

It was inferred from the present work that apple grown in the Balochistan province is a rich source of phytochemicals, antioxidants, mineral contents and effective against marine BL bacteria $V$. logei. The cultivar and sample type were the predominant factors that influenced the contents of phenolic, flavonoids and AoA. Comparatively, apricot peels were found superior to corresponding pulps in the investigated parameters. Hence, peels of these varieties could be essential ingredients as functional foods. Correlation analysis confirms the role of phenolics to contribute to AoA. Bioluminescence study showed an antivirulence perspective of the peels. However, a detailed investigation of particular bioactive compound (s) could be crucial, particularly in discovering novel antibacterial compounds in apple peels.

\section{ACKNOWLEDGMENTS}


All authors express their appreciation to Higher Education Pakistan (HEC) for funding the research work under the IRSIP (International research support initiative program) scholarship (No. 1-8/HEC/HRD/2019/8769, PIN: IRSIP 43BMS 63) for six months at the University of Bologna, Italy.

\section{Conflict of interest}

The authors declare that there is no conflict of interest.

\section{REFERENCES}

[1] A. Mata, J. P. Ferreira, C. Semedo, T. Serra, C. M. M. Duarte, and M. R. Bronze, "Contribution to the characterization of Opuntia spp. juices by LC-DAD-ESI-MS/MS," Food Chem., vol. 210, pp. 558-565, 2016, doi: 10.1016/j.foodchem.2016.04.033.

[2] M. Carocho and I. C. F. R. Ferreira, "A review on antioxidants, prooxidants and related controversy: natural and synthetic compounds, screening and analysis methodologies and future perspectives," Food Chem. Toxicol., vol. 51, pp. 15-25, 2013.

[3] A. Konarska, "The structure of the fruit peel in two varieties of Malus domestica Borkh.(Rosaceae) before and after storage," Protoplasma, vol. 250, no. 3, pp. 701-714, 2013.

[4] M. R. Alberto, M. A. Rinsdahl Canavosio, and M. C. Manca de Nadra, "Antimicrobial effect of polyphenols from apple skins on human bacterial pathogens," Electron. J. Biotechnol., vol. 9, no. 3, p. 0, 2006.

[5] J. Wu et al., "Chemical compositional characterization of some apple cultivars," Food Chem., vol. 103, no. 1, pp. 88-93, 2007.

[6] K. L. Wolfe and R. H. Liu, "Apple peels as a value-added food ingredient," J. Agric. Food Chem., vol. 51, no. 6, pp. 1676-1683, 2003.

[7] R. Tsao, R. Yang, J. C. Young, and H. Zhu, "Polyphenolic profiles in eight apple cultivars using high-performance liquid chromatography (HPLC)," J. Agric. Food Chem., vol. 51, no. 21, pp. 6347-6353, 2003.

[8] L. Lamperi et al., "Polyphenol levels and free radical scavenging activities of four apple cultivars from integrated and organic farming in different Italian areas," J. Agric. Food Chem., vol. 56, no. 15 , pp. 6536-6546, 2008.

[9] I. Konczak and P. Roulle, "Nutritional properties of commercially grown native Australian fruits: Lipophilic antioxidants and minerals," Food Res. Int., vol. 44, no. 7, pp. 23392344, 2011.

[10] "Governament of Pakistan.pdf." .

[11] B. D'Abrosca, S. Pacifico, G. Cefarelli, C. Mastellone, and A. Fiorentino, "Limoncella'apple, an Italian apple cultivar: Phenolic and flavonoid contents and antioxidant activity," Food Chem., vol. 104, no. 4, pp. 1333-1337, 2007. 
[12] S. Gorinstein et al., "Comparative contents of dietary fiber, total phenolics, and minerals in persimmons and apples," J. Agric. Food Chem., vol. 49, no. 2, pp. 952-957, 2001.

[13] C. Henríquez et al., "Determination of antioxidant capacity, total phenolic content and mineral composition of different fruit tissue of five apple cultivars grown in Chile," Chil. J. Agric. Res., vol. 70, no. 4, pp. 523-536, 2010.

[14] M. Manzoor, F. Anwar, N. Saari, and M. Ashraf, "Variations of antioxidant characteristics and mineral contents in pulp and peel of different apple (Malus domestica Borkh.) cultivars from Pakistan,” Molecules, vol. 17, no. 1, pp. 390-407, 2012.

[15] A. of O. A. Chemists, Official Methods of Analysis: Changes in Official Methods of Analysis Made at the Annual Meeting. Supplement, vol. 15. Association of Official Analytical Chemists, 1990.

[16] V. L. Singleton and J. A. Rossi, "Colorimetry of total phenolics with phosphomolybdicphosphotungstic acid reagents," Am. J. Enol. Vitic., vol. 16, no. 3, pp. 144-158, 1965.

[17] J. Zhishen, T. Mengcheng, and W. Jianming, "The determination of flavonoid contents in mulberry and their scavenging effects on superoxide radicals," Food Chem., vol. 64, no. 4, pp. 555-559, 1999.

[18] Y. Chen, R. Zhang, C. Liu, X. Zheng, and B. Liu, "Enhancing antioxidant activity and antiproliferation of wheat bran through steam flash explosion," J. Food Sci. Technol., vol. 53, no. 7, pp. 3028-3034, 2016.

[19] R. J. Ruch, S. Cheng, and J. E. Klaunig, "Prevention of cytotoxicity and inhibition of intercellular communication by antioxidant catechins isolated from Chinese green tea," Carcinogenesis, vol. 10, no. 6, pp. 1003-1008, 1989.

[20] R. Murugan and T. Parimelazhagan, "Comparative evaluation of different extraction methods for antioxidant and anti-inflammatory properties from Osbeckia parvifolia Arn.-An in vitro approach,” J. King Saud Univ., vol. 26, no. 4, pp. 267-275, 2014.

[21] J. O. Olugbami, M. A. Gbadegesin, and O. A. Odunola, "In vitro free radical scavenging and antioxidant properties of ethanol extract of Terminalia glaucescens," Pharmacognosy Res., vol. 7, no. 1, p. 49, 2015.

[22] S. Girotti, L. Bolelli, A. Roda, G. Gentilomi, and M. Musiani, "Improved detection of toxic chemicals using bioluminescent bacteria," Anal. Chim. Acta, vol. 471, no. 1, pp. 113-120, 2002.

[23] S. Sahito, T. G. Kazi, M. A. Jakhrani, G. H. Kazi, G. Q. Shar, and M. A. Memon, "Elemental investigation of Momordica charantia linn. and Syzigium jambolana Linn. using atomic absorption spectrophotometer," Nucl., 2002.

[24] S. Ali, T. Masud, and K. S. Abbasi, "Physico-chemical characteristics of apricot (Prunus armeniaca L.) grown in Northern Areas of Pakistan," Sci. Hortic. (Amsterdam)., vol. 130, no. 2, pp. 386-392, 2011. 
[25] G. Campeanu, G. Neata, and G. Darjanschi, "Chemical composition of the fruits of several apple cultivars growth as biological crop," Not. Bot. Horti Agrobot. Cluj-Napoca, vol. 37, no. 2, pp. 161-164, 2009.

[26] S. Rosnah, W. K. Wong, M. Noraziah, and H. Osman, "Chemical composition changes of two water apple (Syzygium samaragense)," Int. Food Res. J., vol. 19, no. 1, p. 167, 2012.

[27] R. O. Adeleke and O. A. Abiodun, "Nutritional composition of breadnut seeds (Artocarpus camansi).," African J. Agric. Res., vol. 5, no. 11, pp. 1273-1276, 2010.

[28] F. R. Harker et al., "Consumer liking for kiwifruit flavour: A meta-analysis of five studies on fruit quality," Food Qual. Prefer., vol. 20, no. 1, pp. 30-41, 2009.

[29] R. B. Jordan, E. F. Walton, K. U. Klages, and R. J. Seelye, "Postharvest fruit density as an indicator of dry matter and ripened soluble solids of kiwifruit," Postharvest Biol. Technol., vol. 20, no. 2, pp. 163-173, 2000.

[30] J. W. Palmer, F. R. Harker, D. S. Tustin, and J. Johnston, "Fruit dry matter concentration: A new quality metric for apples," J. Sci. Food Agric., vol. 90, no. 15, pp. 2586-2594, Dec. 2010, doi: $10.1002 /$ jsfa.4125.

[31] F. G. K. Vieira, G. D. S. C. Borges, C. Copetti, R. D. D. M. C. Amboni, F. Denardi, and R. Fett, "Physico-chemical and antioxidant properties of six apple cultivars (Malus domestica Borkh) grown in southern Brazil," Sci. Hortic. (Amsterdam)., vol. 122, no. 3, pp. 421-425, 2009.

[32] M. A. Al-Farsi and C. Y. Lee, "Optimization of phenolics and dietary fibre extraction from date seeds," Food Chem., vol. 108, no. 3, pp. 977-985, 2008.

[33] M. Kalinowska, A. Bielawska, H. Lewandowska-Siwkiewicz, W. Priebe, and W. Lewandowski, "Apples: Content of phenolic compounds vs. variety, part of apple and cultivation model, extraction of phenolic compounds, biological properties," Plant Physiol. Biochem., vol. 84, pp. 169-188, 2014.

[34] Ş. Karaman, E. Tütem, K. S. Başkan, and R. Apak, "Comparison of antioxidant capacity and phenolic composition of peel and flesh of some apple varieties," J. Sci. Food Agric., vol. 93, no. 4, pp. 867-875, 2013.

[35] B. Łata, A. Trampczynska, and J. Paczesna, "Cultivar variation in apple peel and whole fruit phenolic composition," Sci. Hortic. (Amsterdam)., vol. 121, no. 2, pp. 176-181, 2009.

[36] T. K. McGhie, M. Hunt, and L. E. Barnett, "Cultivar and growing region determine the antioxidant polyphenolic concentration and composition of apples grown in New Zealand," $J$. Agric. Food Chem., vol. 53, no. 8, pp. 3065-3070, 2005.

[37] R. Tsao, R. Yang, S. Xie, E. Sockovie, and S. Khanizadeh, "Which polyphenolic compounds contribute to the total antioxidant activities of apple?," J. Agric. Food Chem., vol. 53, no. 12, pp. 4989-4995, 2005. 
[38] A. Duda-Chodak, T. Tarko, P. Satora, P. Sroka, and T. Tuszyński, "The profile of polyphenols and antioxidant properties of selected apple cultivars grown in Poland," J. Fruit Ornam. Plant Res., vol. 18, no. 2, pp. 39-50, 2010.

[39] R. Veberic, M. Trobec, K. Herbinger, M. Hofer, D. Grill, and F. Stampar, "Phenolic compounds in some apple (Malus domestica Borkh) cultivars of organic and integrated production," J. Sci. Food Agric., vol. 85, no. 10, pp. 1687-1694, 2005.

[40] L. Guidi, E. Degl'Innocenti, D. Remorini, R. Massai, and M. Tattini, "Interactions of water stress and solar irradiance on the physiology and biochemistry of Ligustrum vulgare," Tree Physiol., vol. 28, no. 6, pp. 873-883, 2008.

[41] L. Jakobek, R. García-Villalba, and F. A. Tomás-Barberán, "Polyphenolic characterisation of old local apple varieties from Southeastern European region," J. food Compos. Anal., vol. 31, no. 2, pp. 199-211, 2013.

[42] S. E. W. Opitz, S. Smrke, B. A. Goodman, and C. Yeretzian, "Methodology for the measurement of antioxidant capacity of coffee: A validated platform composed of three complementary antioxidant assays," in Processing and Impact on Antioxidants in Beverages, Elsevier, 2014, pp. 253-264.

[43] N. F. Santos-Sánchez, R. Salas-Coronado, C. Villanueva-Cañongo, and B. HernándezCarlos, Antioxidant compounds and their antioxidant mechanism. IntechOpen London, UK, 2019.

[44] A. K. Tareen, M. A. Panezai, A. Sajjad, J. K. Achakzai, A. M. Kakar, and N. Y. Khan, "Comparative analysis of antioxidant activity, toxicity, and mineral composition of kernel and pomace of apricot (Prunus armeniaca L.) grown in Balochistan, Pakistan,” Saudi J. Biol. Sci., 2021.

[45] S. S. Mitić, B. T. Stojanović, M. B. Stojković, M. N. Mitić, and J. L. Pavlović, "Total phenolics, flavonoids and antioxidant activity of different apple cultivars," Bulg. Chem. Commun., p. 326, 2013.

[46] F. G. K. Vieira, G. D. S. C. Borges, C. Copetti, P. F. Di Pietro, E. da Costa Nunes, and R. Fett, "Phenolic compounds and antioxidant activity of the apple flesh and peel of eleven cultivars grown in Brazil," Sci. Hortic. (Amsterdam)., vol. 128, no. 3, pp. 261-266, 2011.

[47] I. Górniak, R. Bartoszewski, and J. Króliczewski, "Comprehensive review of antimicrobial activities of plant flavonoids," Phytochem. Rev., vol. 18, no. 1, pp. 241-272, 2019.

[48] S. Quideau, D. Deffieux, C. Douat-Casassus, and L. Pouysegu, "Plant polyphenols: chemical properties, biological activities, and synthesis," Angew. Chemie Int. Ed., vol. 50, no. 3, pp. 586-621, 2011.

[49] J. Boyer and R. H. Liu, "Apple phytochemicals and their health benefits," Nutr. J., vol. 3, no. 1, pp. 1-15, 2004. 
[50] J. Sun, Y.-F. Chu, X. Wu, and R. H. Liu, "Antioxidant and antiproliferative activities of common fruits," J. Agric. Food Chem., vol. 50, no. 25, pp. 7449-7454, 2002.

[51] M. Giada, "Food phenolic compounds: main classes, sources and their antioxidant power," Oxidative Stress chronic Degener. Dis. role antioxidants. InTech, pp. 87-112, 2013.

[52] F. Fratianni, R. Coppola, and F. Nazzaro, "Phenolic composition and antimicrobial and antiquorum sensing activity of an ethanolic extract of peels from the apple cultivar Annurca," $J$. Med. Food, vol. 14, no. 9, pp. 957-963, 2011.

[53] A. R. Vincente, G. A. Manganaris, C. M. Ortiz, G. O. Sozzi, and C. H. Crisosto, "Nutritional quality of fruits and vegetables," in Postharvest handling, Elsevier, 2014, pp. 69122.

[54] E. Commission, "Commission Directive 2001/22/EC of 8 March 2001 laying down the sampling methods and the methods of analysis for the official control of the levels of lead, cadmium, mercury and 3-MCPD in foodstuffs," Off. J., vol. 50, pp. 14-21, 2001.

[55] M. E. Osawaru, M. C. Ogwu, and R. O. Aiwansoba, "Hierarchical approaches to the analysis of genetic diversity in plants: A systematic overview," Univ. Mauritius Res. J., vol. 21, 2015. 